\title{
Voluntary Additional Health Insurance in the European Union: Free Market or Regulation?
}

\author{
Piet Calcoen* and Wynand P.M.M. van de Ven \\ Department of Health Policy and Management, Erasmus University \\ Rotterdam, Rotterdam, The Netherlands \\ pietcalcoen@hotmail.com
}

\begin{abstract}
Recent European Court of Justice (ECJ) case law has highlighted apparent inconsistencies in ECJ rulings on the regulation of voluntary additional health insurance. In 2013, the ECJ upheld Belgian regulations limiting the operation of the free market by restricting increases in premium rates of additional health insurance contracts. By contrast, in 2012, an ECJ ruling required Slovenia to repeal such restrictive legislation and not to hinder the operation of the free market. The objective of this article is to feed the discussion on the question whether and under what conditions free-market-driven additional health insurance in the European Union might be acceptable. We conclude that, provided that basic health insurance effectively covers all essential healthcare (essential healthcare services being broadly defined), additional health insurance could be regulated in the same way as all other non-life insurance.
\end{abstract}

\section{Keywords}

voluntary health insurance - insurance premium rate - regulation - free market - EU law - non-life insurance directives

* Corresponding author. The authors gratefully acknowledge the information on the Slovenian additional health insurance sector provided by Bruno Nikolič (University of Ljubljana). The views expressed in this article are those of the authors and do not necessarily reflect those of the abovementioned person. The authors gratefully acknowledge the comments made by the anonymous reviewers. The authors wish to thank Richard Burton for his corrections and suggestions.

(C) PIET CALCOEN AND WYNAND P.M.M. VAN DE VEN, 2017 | DOI 10.1163/15718093-12460339

This is an open access article distributed under the terms of the prevailing CC-BY-NC license at the time of publication. 
In the European Union (EU), voluntary additional health insurance is, in principle, subject to free market rules and competition. As an exception, governments may impose rules restricting free competition when private health insurance serves as a partial or complete alternative to health cover provided by the statutory social security system ('substitutive health insurance'). In this article, we will focus on 'voluntary additional health insurance', which we define as 'all voluntary individual (not: group) additional private health insurance other than substitutive health insurance' (e.g., complementary or supplementary health insurance).

In 2013, the European Court of Justice (ECJ) ruled that the European insurance directives do not preclude the Belgian government from adopting regulations limiting competition in the additional health insurance market in order to protect consumers against sharp and unexpected increases in premium rates. ${ }^{1}$ The ECJ did not concur with the opinion of the European Commission, which considered that the Belgian legislation at issue was contrary to the principle of freedom to set rates. As will be discussed below, this judgment differs from a 2012 ruling where the ECJ required Slovenia to repeal its restrictive legislation on increases in premium rates. ${ }^{2}$

In this article, we will analyse the impact of these two ECJ rulings on the application of free-market principles on voluntary additional health insurance markets in the EU. We will discuss the arguments made in favour and against restrictive price regulation. In addition to an analysis of the Belgian and Slovenian cases, we will also refer to the concept of services of general economic interest and to the ECJ ruling in the $B U P A$ case $^{3}$ (Ireland). Starting from the Belgian and Slovenian ECJ cases on price regulation in the additional health insurance market, we will broaden the discussion to the question of the extent to which free market rules effectively apply to additional health insurance in the EU. The objective of this article is to feed the discussion on the question whether and under what conditions free-market-driven additional health insurance in the EU might be acceptable.

1 Case C-577/11, DKV Belgium SA v. Association belge des consommateurs Test-Achats ASBL ECLI:EU:C:2013:146.

2 Case C-185/11, Commission v. Slovenia ECLI:E U:C:2012:43.

3 Case T-289/03, BUPA and others v. Commission [2008] ECR II-81. 
In addition to the general treaty provisions on freedom of establishment (Article 49 of the Treaty on the Functioning of the European Union ('TFEU') ${ }^{4}$ ) and freedom to provide services (Article $56 \mathrm{TFEU}$ ), the EU has adopted specific non-life insurance directives with the aim of increasing competition in the European insurance market. ${ }^{5}$ Recital 19 of the Third Non-Life Insurance Directive ${ }^{6}$ states that 'within the framework of an internal market it is in the policyholder's interest that he should have access to the widest possible range of insurance products available in the Community so that he can choose that which is best suited to his needs'.

When it comes to insurers' freedom to set premium rates, Article 8(3) of the First Non-Life Insurance Directive ${ }^{7}$ and Articles 29 and 39(2) and (3) of the Third Non-Life Insurance Directive provide: '[...] Member States may not retain or introduce prior notification or approval of proposed increases in premium rates except as part of general price-control systems'.

Article 54 of the Third Non-Life Insurance Directive provides an exception to this rule. A Member State's supervisory authority may impose specific measures in the form of restrictions on insurance contracts in the interest of the 'general good', where contracts covering health risks 'may serve as a partial or complete alternative to health cover provided by the statutory social security system'. Where this is the case, a Member State can require private insurers to 'comply with the specific legal provisions adopted by that Member State to protect the general good in that class of insurance.8 A number of legal provisions may be introduced if private cover provides a partial or complete alternative to statutory cover: open enrolment, community rating, lifetime cover, policies

4 Consolidated version of the Treaty on the Functioning of the European Union, oJ C 202, 7 June 2016, pp. 47-200.

5 For an analysis of the relevant Eu legal framework, see F. Paolucci, A. Den Exter and W.P.M.M. van de Ven, 'Solidarity in competitive health insurance markets: analysing the relevant EC legal framework', Health Economics, Policy and Law 1(2) (2006) 107-126.

6 Council Directive 92/49/EEC of 18 June 1992 on the coordination of laws, regulations and administrative provisions relating to direct insurance other than life assurance and amending Directives 73/239/E EC and 88/357/E EC, oJ L 228, 11 August 1992, pp. 1-23 ('Third Non-Life Insurance Directive').

7 Council Directive 73/239/EEC of 24 July 1973 on the coordination of laws, regulations and administrative provisions relating to the taking-up and pursuit of the business of direct insurance other than life assurance, oJ L 228, 16 August 1973, pp. 3-19 (First Non-Life Insurance Directive).

8 Article 54(1) and Recital 24 of the Third Non-Life Insurance Directive. 
standardised in line with the cover provided by the statutory health insurance scheme at a premium rate at or below a prescribed maximum, participation in risk equalisation schemes (referred to as 'loss compensation schemes') and the operation of private health insurance on a technical basis similar to life insurance. ${ }^{9}$ Measures taken to protect the general good must be shown to be necessary and proportional to this aim; not unduly restrict the right of establishment or the freedom to provide services; and apply in an identical manner to all insurers operating within a member state.

In his letter of 25 November 2008, European Commissioner Bolkestein, responding to a question from the Dutch government on the application of $\mathrm{EU}$ regulation to private health insurance, suggested that the Article 54 exception only applies to substitutive health insurance: 'I do not think that it would be proportionate to apply the requirements to any complementary insurance cover offered by private insurers which goes beyond the basic social security package of cover laid down by the legislation.10 ${ }^{10}$ Thomson and Mossialos disagree with the assumption that only substitutive private health insurance provides social protection. They argue that where the statutory benefits package is relatively narrow and/or subject to extensive co-payments, it could be considered that individuals do not have adequate protection from the financial risk associated with ill health unless they purchase additional health insurance covering excluded (and effective) services and/or statutory user charges." ${ }^{11}$ However, the credibility of this argument depends on the extent to which lowincome groups and high-risk groups (e.g., the elderly and chronically ill) effectively have access to such additional cover. Regulation of voluntary additional health insurance that is not affordable for these groups cannot be considered to effectively protect the general good.

Under certain conditions, national governments can restrict the application of free market principles to private health insurance. A restriction on free competition may be justified where it serves overriding requirements relating to the public interest, is suitable for securing the attainment of the objective which it pursues and does not go beyond what is necessary in order to attain it. ${ }^{12}$

Ibid. Article 54(2) and Recital 24.

10 F. Bolkestein, 'Letter from the European Commission to the Dutch Minister of Health, Welfare and Sport', European Commission, 25 November 2003.

11 S. Thomson and E. Mossialos, 'Private health insurance and the internal market', in: E. Mossialos, G. Permanand, R. Baeten and T. Hervey (eds.), Health Systems Governance in Europe: The Role of EU Law and Policy (Cambridge: Cambridge University Press, 2010) pp. 419-460.

Case C-518/o6, Commission v. Italy [2009] ECR I-3491, para. 72. 
In recent years, the ECJ has taken different views in two cases (Commission v. Slovenia (2012) and DKV Belgium SA v. Association belge des consommateurs Test-Achats ASBL (2013) $)^{13}$ on the question whether government intervention in setting the prices of additional health insurance contracts is consistent with EU regulation. On the one hand, in its ruling of 26 January 2012 in Commission v. Slovenia, the Court concluded that Slovenia's rules on complementary health insurance did not comply with the EU non-life insurance Directives. The Court found that a number of provisions in the Slovenian Health Care and Health Insurance Act ('Zakon o zdravstvenem varstvu in zdravstvenem zavarovanju' $($ 'zzVZz')) did not comply with some of the basic freedoms outlined in the EU's non-life insurance Directives. By contrast, by its ruling of 7 March 2013 in $D K V$ Belgium $S A$, the Court upheld the system of restrictive price regulation of existing private health insurance contracts in Belgium. The Court accepted a requirement of prior notification and approval of proposed increases in premium rates in the Belgian context but not in the Slovenian context.

These two cases, which each concern price regulation, illustrate the need for discussion on the appropriate balance between regulation and the operation of the free market in the additional health insurance sector more broadly. This important issue of health policy will be discussed in more depth in section 5 . Before that, in section 4, we will bring into the discussion two legal elements that are relevant to consideration of the appropriate balance to be drawn, the concept of services of general economic interest and the proportionality of national regulation aiming at restricting free market.

\subsection{Slovenia \\ 3.1.1 Health Insurance System}

In 2015, health expenditure per capita in Slovenia - expressed in purchasing power parity - was less than the EU 28 average but above the average for the ten countries that joined the EU in May 2004. ${ }^{14}$ Private health expenditure, comprising voluntary additional health insurance and out-of-pocket expenditure, is close to 30 per cent of total health expenditure. ${ }^{15}$ All Slovenians are covered by compulsory basic health insurance, which is part of a Bismarckian

\footnotetext{
13 Supra notes 1 and 2.

$14 \mathrm{OECD} / \mathrm{EU}$, Health at a Glance: Europe 2016 - State of Health in the EU Cycle (Paris: OECD Publishing, 2016), online at http://dx.doi.org/10.1787/9789264265592-enR, accessed 24 January 2017,

15 In 2015, Slovenia's public spending as share of total health expenditure was 72.2 per cent. Private health expenditure amounted to 27.8 per cent of total health expenditure.
} 
system of social security. Voluntary additional health insurance is quite important in Slovenia, covering about half of private expenditure. ${ }^{16}$ Voluntary additional health insurance was introduced in 1993 to cover co-payments for compulsory health insurance. ${ }^{17}$ Co-payments apply for visits to general practitioners, specialists and hospitals as well as for pharmaceuticals and vary from 5 per cent to 75 per cent. Almost all Slovenians have taken out additional health insurance to cover co-payments. ${ }^{18}$ Additional health insurance is provided by Vzajemna, a non-profit public insurance company, along with Adriatic-Slovenica, Triglav and Merkur, three for-profit insurance companies. ${ }^{19}$ Vzajemna and Adriatic-Slovenica have been active since 1993. In the period 2004-2005, two new commercial companies — Triglav and Merkur — entered into the Slovene market. They launched an overt cream-skimming campaign aimed at younger and healthier insured individuals by offering risk-related premiums. In 2005, a risk-equalisation scheme was adopted. In order to prevent cream-skimming, additional health insurance companies were obliged to participate in the risk-equalisation scheme to level out differences among insurance companies in terms of the costs of healthcare. Insurance companies had to apply a unified flat premium for all insured people, irrespective of sex, age or health status. ${ }^{20}$

3.1.2 Commission $v$. Slovenia ${ }^{21}$

According to the Slovenian Health Care and Health Insurance Act (zzvzz), increases in premium rates of additional health insurance contracts had to be

Source: OECD Health Statistics 2016, figures for 2015, online at http://stats.oecd.org/index .aspx?DataSetCode=HEALTH_STAT, accessed 22 January 2017.

$16 \quad$ Ibid., 14.8 per cent.

17 Reimbursement of co-payments amounted to EUR 404 million in 2014, representing 85 per cent of total expenditure by additional health insurance (EUR 474 million). The remaining EUR 70 million was spent on care not reimbursed by Slovenian social security. S. Thomas, S. Thomson and T. Evetovits, 'Making sense of complementary health insurance', final report, Slovenian Ministry of Public Health, 2015, online at http://www.mz.gov .si/fileadmin/mz.gov.si/pageuploads/Analiza/21012016/21012016Report_Making_sense_ of_CHI_-_Slovenia.pdf, accessed 26 January 2017.

18 Children under 18 years and students under 26 years are excluded from co-payments. Approximately 98 per cent of all individuals who are eligible to pay co-payments have taken out additional health insurance. T. Albreht, E. Turk, M. Toth, J. Ceglar, S. Marn, R. Pribaković Brinovec, M. Schäfer, O. Avdeeva and E. van Ginneken, 'Slovenia: Health system review', Health Systems in Transition 11(3) (2009) 1-168.

19 Ibid.

20 Ibid.

21 Supra note 2. 
notified to and approved by the relevant national supervisory authority. ${ }^{22} \mathrm{On} 23$ March 2007, the European Commission sent a letter of formal notice to Slovenia stating that certain articles of the zzvzz breached the non-life insurance Directives and Articles 56 and 63 TFEU. ${ }^{23}$ Article 63 TFEU was invoked because the zzVzz obliged insurance companies to reinvest at least half of the profits from additional health insurance in the administration of this insurance. ${ }^{24} \mathrm{In}$ response, Slovenia argued that, although additional health insurance was not compulsory, it was part of the Slovenian social security system since it represented a matter of public interest. ${ }^{25}$ In defence of the existing regulation, Slovenia referred to Article 54 of the Third Non-Life Insurance Directive. ${ }^{26}$ Later, in a letter of 26 August 2009, Slovenia proposed to remove the contested articles from the zzvzz. As Slovenia did not ultimately amend the zzvzz, the European Commission referred the case to the ECJ. On 26 January 2012, the ECJ ruled that certain requirements of the ZzVzz were in breach of Article 8(3) of the First Non-Life Insurance Directive and Articles 29 and 39 of the Third Non-Life Insurance Directive, more particularly the requirement of prior notification and approval of proposed increases in premium rates, the requirement of prior agreement of the Minister of Public Health before setting up an additional health insurance business in Slovenia (including notification of all terms and conditions) and the requirement of prior notification and approval of proposed changes of terms and conditions.

The European Commission also argued that Article 62, §2, $4^{\circ}$ zzvzz (requirement that half of the profit resulting from additional health insurance be invested in its administration) and Article 62f, §9 zzvzz (requirement that insurance companies from other Member States appoint a domiciliary agent in Slovenia) did not comply with Articles 56 and 63 TFEU. However, since the Commission's claim on these points was not correctly formulated, the Court dismissed it.

Subsequently, the Slovenian government adapted the zzvzz by removing the contested provisions. The amendments included repeal of Articles 62, §2, $4^{\circ}$ and $62 f$, $\$ 9$ zzVzz, even though the ECJ had not ruled on their compatibility with EU law.

\footnotetext{
22 Article $62, \S 2,6^{\circ}$ zzvzz.

23 Supra note 2, paras. 10 and 12.

24 Article 62, § 2, $4^{\circ}$ zzvzz.

25 Supra note 2, para. 11. For a discussion on the public interest argument see infra section 4.2.

$26 \quad$ Ibid. For further explanation of Article 54, see supra section 2.
} 


\subsection{Belgium \\ 3.2.1 Health Insurance System}

Belgium has a system of compulsory health insurance with a very broad benefits package. Health insurance is part of a Bismarckian social security system. Compulsory health insurance is administered by seven sickness funds. Every citizen is obliged to be a member of a sickness fund.

In 2015, Belgium had the 8th highest healthcare expenditure per capita measured in purchasing power parity among the EU28 countries. ${ }^{27}$ Private expenditure (i.e., out-of-pocket expenditure plus additional health insurance) represents more than 20 per cent of total health expenditure. ${ }^{28}$

Additional health insurance covers less than 5 per cent of total expenditure on health. ${ }^{29}$ Half of this 5 per cent consists of services and benefits provided by the sickness funds to their members and for which the sickness funds request a membership fee. These services and benefits are very diverse, e.g., reimbursement of travel vaccines or reimbursement of the membership fees of sport clubs. In addition to these services and benefits, which are accessible for the entire population, about three-quarters of the population has taken out voluntary additional health insurance, known as 'hospitalisation insurance' ('hospitalisatieverzekering' (Dutch) / 'assurance hospitalisation' (French)). ${ }^{30}$ This hospitalisation insurance covers supplements and co-payments. ${ }^{31}$ There are three types of supplements, which are not covered by compulsory health insurance: fee supplements, room supplements and material supplements.

A fee supplement is an extra fee charged by healthcare providers on top of the official tariff set by the social security regime ('ereloonsupplement' (Dutch) / 'supplément d'honoraires' (French)). ${ }^{32}$ In a hospital setting, fee supplements may only be charged to patients staying in a private, one-bed room.

\footnotetext{
27 Supra note 14.

28 Public funding as share of total expenditure on health amounts to 77.6 per cent. Private expenditure represents 22.4 per cent of total health expenditure, see supra note 15 .

29 In 2014, voluntary additional health insurance represented 4.4 per cent of total health expenditure. OECD Health Statistics 2016, see supra note 15.

30 Other types of additional health insurance, such as dental insurance or insurance for outpatient costs, are taken out by less than 5 per cent of the Belgian population.

31 The term 'statutory user charges' can also be used instead of the term 'co-payments'. Statutory user charges represent on average 38 per cent of total patient bill. Mutualité Chrétienne, '12e Baromètre MC de la facture hospitalière', 21 November 2016, online at https://www.mc.be/actualite/communique-presse/2016/barometre_hospitalier_2016.jsp, accessed 24 January 2017.

In Anglo-American contexts, the terms 'extra billing' or 'balance billing' are used.
} 
In 2015 , one out of every four patients stayed in a private room. ${ }^{33}$ In hospitals, fee supplements range between one and three times the official tariff, with significant variations between the supplements in different regions. ${ }^{34}$ In a similar way to a fee supplement, a room supplement is charged by the hospital for the use of a private, one-bed room. When a stay in a private room is necessary because of medical reasons, room supplements may not be charged. A 'material' supplement is requested for medical material which is not (yet) reimbursed by social security, e.g., non-reimbursable pharmaceuticals or a new hip implant. ${ }^{35}$ The costs linked to the use of a private hospital room - i.e., fee and room supplements - account for about half of total reimbursements made by hospitalisation insurance programmes. ${ }^{36}$ Whereas the total patient bill has been decreasing over the past ten years, this is not the case for fee supplements which have been steadily increasing. ${ }^{37}$

In order to curb the - often high — premium rate increases under hospitalisation insurance contracts, a 'medical index' has been created by law. Premium rates can only be increased in line with the consumer prices index or the medical index. ${ }^{38}$ Only when an additional health insurance product is (expected to be) loss-making may an insurer request the supervisory authority, the National Bank of Belgium, for permission to increase premiums. ${ }^{39}$

33 In 2015, 23 per cent of all Belgian patients stayed in a private room for a regular hospitalisation (including at least one night), see supra note 31.

34 Most Flemish hospitals charge 100 per cent of the official tariff, most Walloon hospitals 200 per cent, and most Brussels hospitals 300 per cent.

35 On average, material supplements account for about 7 per cent of total patient bill, see supra note 31 .

36 The exact figure is 49 per cent (2015), see supra note 31.

37 After adjustment for inflation, supplementary fees have increased by 32 per cent between 2004 and 2015, whereas total hospital bill for the patient has decreased by 5 per cent. In 2015, supplementary fees represented 61 per cent of the average patient bill for a private hospital room, see supra note 31.

38 A law introduced on 17 June 2009 restricted increases in premium rates for existing contracts to increases in the consumer price index or the medical index if and in so far as the evolution of the medical index exceeds that of the consumer price index (Article 204 Insurance Law). The medical index reflects the evolution of the patient bill. Because the medical index did not include a provision to revalorise the ageing reserves, the medical index was annulled by the administrative court on 29 December 2011. By royal decree of 16 March 2016, a new medical index has been created, including -on top of the claims evolution- a provision of maximum 2 per cent to cover the revalorisation of the ageing reserves.

39 Art. 204, §4 Insurance Law ('Loi du 4 avril 2014 relative aux assurances, Moniteur belge, 30 April 2014'). 
In 2010, the Belgian consumer organisation Test-Achats ASBL, and the Belgian professional association of insurance companies Assuralia, lodged an action for annulment of the aforementioned law of 17 June 2009 on private additional health insurance contracts. In a judgment of 31 May 2011, the Belgian Constitutional Court upheld the legal restrictions on increases in premium rates. ${ }^{40}$ It stated that it was the goal of the legislator to protect consumers, particularly with a view to preventing them from being faced with sharp, unexpected increases in insurance premium rates.

In January 2010, DKV Belgium SA, a private insurance company offering additional health insurance products, increased insurance premium rates by 7.84 per cent, well before the publication of the official medical index later that year. On 22 February 2010, Test-Achats brought an action for an injunction before the President of the Commercial Court in Brussels seeking to have $\mathrm{DKV}$ ordered to reverse its decision to increase premiums. By judgment of 20 December 2010, the Court upheld Test-Achats' complaint. DKV appealed against that judgment before the Brussels Court of Appeal. The Brussels Court of Appeal requested a preliminary ruling from the ECJ on the compatibility with EU law of Belgium's legislation restricting premium rate increases of additional health insurance contracts. ${ }^{41}$ The ECJ, in its judgment of 7 March 2013, held that 'the non-life insurance directives do not preclude the Belgian legislation restricting increases in premium rates'. The ECJ ruled that the Belgian rules do not constitute a breach of Articles 49 and 56 TFEU, 'provided that there are no less restrictive measures which might be used to achieve, under the same conditions, the objective of protecting consumers against sharp, unexpected increases in insurance premium rates, which is for the national court to ascertain'. ${ }^{42}$

Following the ECJ's ruling, DKV argued before the national court that an ex post facto review of rate increases constituted a less restrictive alternative, compared to a prior review (as the non-life insurance Directives specifically prohibit retaining or introducing prior notification or approval of proposed increases in premium rates). However, on 22 February 2016, the Brussels Court of Appeal ruled that an ex post facto review does not represent a less restrictive alternative but only a different 'modus operandi'.

\footnotetext{
40 Arrêt de la Cour constitutionnel 9o/2011 du 31 mai 2011, Moniteur belge, 10 August 2011.

$41 D K V$ Belgium SA v. Association belge des consommateurs Test-Achats ASBL, see supra note 1, para. 17 .

42 Ibid., paras. 48 and 49.
} 
In its ruling, the ECJ stressed the fact that a system of premium rate increases such as that at issue does not prohibit insurance undertakings from freely setting the basic premium and from taking account of the higher costs that the insurance coverage will entail for them when the insured party becomes older. ${ }^{43}$ Previously, the Belgian Constitutional Court had also defended the contested regulation with the argument that the insurer can freely determine all elements of the contract — including the premium — at the moment the contract is concluded. ${ }^{44}$

The apparent inconsistency in the ECJ's recent case law has led to uncertainty as to the compatibility with EU law of restrictions on increases in premium rates. The question is to what extent free market rules effectively apply to additional health insurance in the $\mathrm{EU}$. An important element in the discussion is how the appropriateness of the restrictive measures taken by Member States can be assessed. In this section, we will discuss a set of criteria developed by the European Commission to test the proportionality of national regulation of private additional health insurance. We will also discuss the concept of services of general economic interest (SGEIs). When an additional health insurance scheme can be defined as an SGEI, the application of free market rules to that scheme can be restricted.

As discussed in section 3, while the ECJ held that Slovenian requirements of prior notification and approval of increases in premium rates of additional health insurance contracts were not compliant with the European non-life insurance Directives, the ECJ found the Belgian regime compliant.

In the Belgian case, the European Commission considered that the restrictions on increases in premium rates were contrary to the principle of freedom to set rates. ${ }^{45}$ In its ruling, the ECJ agreed that such a regulatory regime for premium rate increases in one Member State was liable to dissuade insurance undertakings established in other Member States from opening a branch in that first Member State or to offer their services there. The Court reasoned that those undertakings would have to determine their premium positioning and, therefore, their commercial strategy when they first set their premiums, with the risk that future premium rate increases would be insufficient to cover the

\footnotetext{
43 Ibid., para. 45 .

44 Supra note 40, para. B.13.7.3.

45 Cf. Commission v. Italy, see supra note 12, para. 101.
} 
costs with which they will be faced. However, the Court recalled that a restriction on the freedom of establishment or the freedom to provide services may be justified where it serves overriding requirements relating to the public interest, is suitable for securing the attainment of the objective which it pursues and does not go beyond what is necessary in order to attain it. ${ }^{46}$ In past cases, the ECJ has accepted the objective of consumer protection, which was advanced by the Belgian government to defend the contested regulations, as an 'overriding requirement relating to the public interest'. ${ }^{4}$

As for the suitability of the restrictive Belgian regulation for the attainment of the objective it pursues, the European Commission expressed serious doubts. ${ }^{48}$ The Commission considered that it might prove difficult for the regulator to reject proposed increases in premium rates for loss-making additional health insurance products. If this were the case, premium increases would not be prevented and the consumer would not be protected against sharp, unforeseen increases in premium rates. In other words, the Commission had serious doubts about the effectiveness of the regulation.

\subsection{Proportionality of the Contested Regulation}

In the $D K V$ case, the European Commission proposed five criteria to assess the proportionality of national regulation relating to additional health insurance: 49 (1) the nature of the additional health insurance at issue (i.e., whether substitutive, duplicative, supplementary or complementary), with national measures being more proportionate in case of substitutive health insurance; (2) the expenditure by additional health insurance as a share of total national health expenditure, with national measures being more proportionate in case this share is increasing; (3) the objective of the public interest rationale invoked: granting access to additional health insurance irrespective of age and health status (and thus protecting the weakest in society) or protecting consumers who freely concluded their contract in a competitive market, with national measures being more proportionate in case the first objective is aimed at; (4) the existence of a competitive insurance market, which succeeds in creating a wider choice for the consumer and a decrease in premium rates, with national measures being more proportionate in case there is no really competitive insurance market; (5) the existence of other, less restrictive measures.

\footnotetext{
46 Cf. ibid., para. 72.

47 Cf. Case 205/84, Commission v. Germany [1986] ECR 3755, paras. 32-33.

48 Commission Européenne, Observations écrites dans l'affaire C-577/11, Brussels, 28 February 2012 (JUR $(2012) 250478 \mathrm{cV} / \mathrm{tm})$.

Ibid.
} 
What would be the consequences of applying these five criteria to the Slovenian and the Belgian cases?

(1) Nature of additional health insurance: Both in Belgium and Slovenia, additional health insurance is not substitutive but complementary and supplementary. In Belgium, about half of total expenditure by additional health insurance is spent on providing access to a private hospital room. There are no studies available proving that the quality of care in a private room in a Belgian hospital is better than in a double or common room. In Slovenia, co-payments represent $85 \%$ of total reimbursement by additional health insurance. Therefore, as to this criterion, the Slovenian regulation may be considered more proportionate than the Belgian regulation.

(2) Expenditure by additional health insurance as a share of total expenditure on healthcare: While additional health insurance covers 14.8 per cent of total expenditure on healthcare in Slovenia, the figure reaches only 4.4 per cent in Belgium (2014). In fact, the share of total health expenditure covered by additional health insurance in Belgium has dropped from 5.1 per cent in 2003 to 4.4 per cent in 2014. Over the same period, in Slovenia, there has been an increase from 13.9 per cent to 14.8 per cent. ${ }^{50}$ So far as this criterion is concerned, the Slovenian regulation may be considered more proportionate than the Belgian regulation.

(3) Objective of public interest: Due to the existence of community rating in Slovenia, protecting consumers against sharp, unexpected increases in insurance premium rates equally serves the objective of granting access to additional health insurance, irrespective of age and health status (by keeping premium rates affordable) and the objective of protecting consumers who freely conclude their contract in a competitive market. This is not the case for the Belgian market. In Belgium, insurers are completely free to set premium rates for new clients. New clients who suffer from a pre-existing condition may have to pay an extra premium. Once a contract is concluded, given their higher initial premium, high risk clients will be more impacted by subsequent premium increases (in absolute terms). New clients are not protected by the restrictive regulation on increases in premium rates since this regulation is limited to existing contracts. Since the Slovenian regulation also affects access to additional health insurance, it appears to be more proportionate than the Belgian regulation. 
(4) Existence of a competitive insurance market: The Belgian health insurance market is more competitive than the Slovenian market. There is both a larger number of insurers and a bigger variety in premium levels in Belgium. In Slovenia, there are only 4 insurers, whose premium levels are close to each other, ${ }^{51}$ whereas in Belgium there are over 20 insurers. ${ }^{52}$ For these reasons, the Slovenian regulation may be more proportionate than the Belgian regulation as far as this criterion is concerned.

(5) Alternative measure possible: In its reasoned opinion on the Belgian case, the European Commission put forward a number of alternative measures: better information for consumers underwriting additional health insurance; a framework for contested contractual clauses; an obligation to offer a standard contract with limited premiums to vulnerable groups (cf. the 'Basistarif' offered by private basic health insurance in Germany); a limitation of the technical part of the premium (i.e., pure premium and security loadings) in combination with a more flexible framework for the commercial part of the premium (i.e., administrative and commercial costs); a risk equalisation system..$^{53}$ However, some of these supposedly less restrictive measures may well be more restrictive than linking premium increases to a price index (e.g., an obligation to offer a standard contract with limited premiums to vulnerable groups).

Given that additional health insurance expenditure as a share of total healthcare expenditure is much larger in Slovenia and the Slovenian additional health insurance market is less competitive than the Belgian market, it is remarkable that the ECJ upheld the Belgian regulatory regime but found the Slovenian regime incompatible with EU law. Article 54 of the Third Non-Life Insurance Directive explicitly allows EU Member States to restrictively regulate private health insurance that serves as a partial or complete alternative to health cover provided by the statutory social security system. According to this criterion, since additional healthcare in Slovenia mainly covers co-payments $(85 \%)$ and makes healthcare more accessible, the proportionality test rather points towards allowing restrictive regulation to be introduced in Slovenia.

\footnotetext{
51 Supra note 17 (source).

52 Five Belgian sickness funds offer voluntary additional health insurance products and so are more than 15 private insurance companies, online at http://www.assuralia.be/images/ docs/stats/NL/04_marktsamenstelling/04_11_top15-ziekte.htm, accessed 25 January 2017. Supra note 48 .
} 
Since the ECJ apparently accepted regulation of premium rate increases in Belgium but not in Slovenia, it is not clear whether this kind of regulation could be adopted by other Eu Member States.

\subsection{Can Additional Health Insurance Be Considered as a Service of General Economic Interest?}

The qualification of an additional health insurance scheme as a service of general economic interest (SGEI) can serve as a justification for national regulation restricting the operation of the free market. SGEIs are commonly defined as economic activities that would not be generated by market forces alone or at least not in the form of an affordable service available to all on a nondiscriminatory basis. ${ }^{54}$ SGEIs are carried out in the public interest under conditions defined by the State, which imposes a public service obligation on one or more providers. ${ }^{55}$ The concept 'service of general economic interest' (SGEI) is mentioned in Article 106(2) Treaty of the Functioning of the European Union (TFEU).

A key value of EU Member States' healthcare systems, which applies to welfare services more generally, is universal access or coverage. ${ }^{56}$ To guarantee universal coverage, the national government plays a vital role in regulating market-oriented systems. After all, the healthcare market is characterised by several instances of market failure, for instance information asymmetry and risk selection. ${ }^{57}$

When a service is determined to be an SGEI, Member States may enact measures which would otherwise be contrary to the rules of the Treaties, notably the competition rules. Member States retain a wide discretion to define SGEIs,

54 J. Almunia, 'Reform of the state aid rules for services of general economic interest (SGEI) and decisions on WestLB, Bank of Ireland and France Telecom', Press conference, Brussels, 20 December 2011. SPEECH/11/901.

55 European Commission, 2011, State aid: Commission adopts new package on state aid rules for services of general economic interest (SGEI) - frequently asked questions, online at http://europa.eu/rapid/press-release_MEMO-11-929_en.htm accessed 25 January 2017.

56 U. Neergaard, 'Services of general economic interest: the nature of the beast', in: M. Krajewski, U. Neergaard and J.W. van de Gronden (eds.), The Changing Legal Framework for Services of General Interest in Europe — between Competition and Solidarity (The Hague: Asser Press, 2009) pp. 17-50.

57 S. Lavrijssen and S. de Vries, 'Chapter 19, Netherlands', in: Krajewski et al. (eds.), ibid., pp. $383-422$. 
i.e., to use the concept of an SGEI as a tool to intervene in the market. This discretion is subject only to a test for manifest error of assessment. ${ }^{58}$

The closest attempt at clarifying the 'manifest error of assessment' test was made in BUPA where the European Court of Justice (ECJ) noted that the minimum criteria all SGEIs must fulfil are the presence of an act of the public authority entrusting the operators in question with an SGEI mission and the universal and compulsory nature of that mission. ${ }^{59}$

In $B U P A$, the ECJ deferred to the principal prerogative of the Member States to define their services of general economic interest. The case concerned an Irish law that established a risk equalisation scheme for private medical insurance. Private insurers whose clients were below the average risk profile - like BUPA - would have to pay a fee, while insurance companies that provided insurance coverage for clients above the average risk profile were entitled to receive a payment. Claiming that the equalisation scheme constituted a breach of EU competition law, BUPA brought proceedings before the EU courts in the course of which the question arose whether private medical insurance was a public service that could fall under Article 106(2) TFEU.

In Ireland, a private medical insurance system operates alongside a tax based system. According to the facts of the case, approximately 50 per cent of the Irish population had taken out private insurance with one of the three private insurers. BUPA was one of the three insurance companies, but withdrew from the market in 2007 after its appeal against the introduction of a risk equalisation scheme was rejected. The idea of setting up a risk equalisation scheme was that it should contribute to the attainment of the public interest objectives served by private insurance, which are open enrolment (anyone under the age of 65 must be accepted), lifetime cover, community rating and minimum benefits policy. ${ }^{60}$

One aspect of the case which is important to be discussed for the purposes of this article is that the ECJ classified private medical insurance as an SGEI, even though only about 50 per cent of the Irish population was covered by this additional insurance when the case was filed. ${ }^{61}$ The ECJ addressed this fact, and the requirement of universality which it itself had specified as a mandatory

58 G.S. Ølykke and P. Møllgaard, 'What is a service of general economic interest?', European Journal of Law and Economics 41(1) (2016) 205-241.

59 BUPA, see supra note 3, para. 172.

6o S. de Vries, 'BUPA: a healthy case, in the light of a changing constitutional setting in Europe?', in: J.W. van de Gronden, M. Krajewski, U. Neergaard and E. Szyszczak (eds.) Health Care and EU Law (The Hague: Asser Press, 2009) pp. 295-318.

$61 \quad B U P A$, see supra note 3, para. 17. 
characteristic of an SGEI, by stating that: "The compulsory nature of the service and, accordingly, the existence of an SGEI mission [is] established if the service-provider is obliged to contract, on consistent conditions, without being able to reject the other contracting party. That element makes it possible to distinguish a service forming part of an SGEI mission from any other service provided on the market and, accordingly, from any other activity carried out in complete freedom'.62 In other words, as long as the service is available to all of the population, the condition of universality is satisfied. ${ }^{63}$ The essential core of the definition of an SGEI thus lies in their potentially universal nature.

In the $B U P A$ case, the ECJ concluded Irish additional health insurance to be an SGEI.

When the minimum criteria of an SGEI are fulfilled, a violation of the competition rules can potentially be justified under Article 106(2) TFEU.

Coming back to the two cases at issue, the question arises whether Slovenian additional health insurance could be defined as an SGEI. Nikolič lists several arguments to defend this position. ${ }^{64}$ First, additional health insurance is an economic activity. Health insurance companies offer voluntary health insurance coverage and take on the financial risk of engaging in this line of business. Second, the Slovenian legislator has stated that additional health insurance is a part of the social security system. ${ }^{65}$ Additional health insurance is an important and indispensable source of financing for the Slovenian healthcare system. ${ }^{66}$ The majority of the Slovenian population has taken out additional health insurance. Statutory user charges (co-payments) make up 85 per cent of total reimbursements by the Slovenian additional health insurance scheme. Third, the specific obligations, i.e., community rating, open enrolment and lifetime cover, which insurance companies offering additional health coverage have to respect, have been decreed by the legislator. ${ }^{67}$ Fourth, Slovenian additional health insurance can be ascribed a universal and compulsory nature since insurance companies are obliged to contract without being able to reject the other contracting party (cf. open enrolment).

\footnotetext{
62 Ibid., para. 190.

63 Supra note 57.

64 B. Nikolič, 'Slovenian complementary health insurance as a service of general economic interest', International Public Administration Review 13(1) (2015) 49-67.

65 Art. 62 zzvzz.

66 Additional health insurance covers over half of private health expenditure with private health expenditure representing close to 30 per cent of total health expenditure.

67 Art. 62-62c zzvzz.
} 
Unlike the Belgian public interest argument - consumer protection Slovenia's public interest argument that Slovenian additional health insurance ought to be considered as a part of the social security system was rejected by the ECJ.

\section{Free Market or Regulation?}

A clear indication of how the organisation of additional health insurance within the EU should evolve cannot be derived from the recent ECJ case law. Should competition be fostered or should more regulation be imposed? Starting from the Belgian and Slovenian ECJ cases on price regulation in the additional health insurance market, the discussion is broadened to the question of the extent to which free market rules effectively apply to additional health insurance in the EU. The case law discussed above can serve as a starting point for an evaluation of where we stand today and what we should be heading for. What is the future role of additional health insurance within the framework of social health insurance systems in the EU? This article aims at stimulating the discussion on how additional health insurance ought to be organised in order to generate added value for the healthcare system without jeopardising equity concerns such as equal access to essential healthcare.

According to the European Commission, consumers' interests are best protected by promoting free market principles: 'competition encourages enterprise and efficiency, creates a wider choice for consumers and helps reduce prices and improve quality'.68 However, according to Thomson and Mossialos, there is no evidence to suggest that the expected benefits of competition have, as yet, materialised in the private health insurance sector. ${ }^{69}$ Private health insurance premiums have risen rather than fallen, often faster than inflation in the health sector as a whole, while insurers' expansion across national borders has been limited to cross-border mergers and acquisitions, rather than genuinely new entrants to the market. ${ }^{70,71}$

68 European Commission, 'Why is competition policy important for consumers?', 16 April 2012, accessed 26 January 2017, http://ec.europa.eu/competition/consumers/ why_en.html.

69 Supra note 11.

70 E. Mossialos and S. Thomson, Voluntary Health Insurance in the European Union (Copenhagen: World Health Organization, 2004), online at www.euro.who.int/_data/ assets/pdf_file/ooo6/98448/E84885.pdf, accessed 26 January 2017.

71 A. Sagan and S. Thomson, Voluntary Health Insurance in Europe, Role and Regulation (Brussels: European Observatory on Health Systems and Policies, 2016), online at http:// 
Equal access to healthcare is at the core of equity in health which implies that ideally everyone should have a fair opportunity to attain their full health potential and, more pragmatically, that no one should be disadvantaged from achieving this potential, if it can be avoided. ${ }^{72}$ The Constitution of the World Health Organisation sets out the following principle as 'basic to the happiness, harmonious relations and security of all peoples': 'The enjoyment of the highest attainable standard of health is one of the fundamental rights of every human being without distinction of race, religion, political belief, economic or social condition: ${ }^{73}$

Equity of access to healthcare services can be improved by defining essential healthcare services. ${ }^{74}$ Essential healthcare services should be made accessible to everyone within the healthcare system. The Committee on Choices in Health Care, the so-called Dunning Committee, established in 1990 in the Netherlands, has developed a set of four principles, to be applied successively, in order to delineate essential from non-essential healthcare services: necessity, effectiveness, efficiency, and individual responsibility. The principle of necessity is defined very broadly, basically meaning any treatment that is necessary to maintain or restore health, or to relieve suffering. ${ }^{75}$ With regard to the principle of effectiveness, only interventions where there is evidence for an effect are covered. The services to be covered are further narrowed down by those that give value for money, by only funding efficient services. Finally, services that are best dealt with by the individuals themselves are excluded (i.e., services that can easily be paid for by the individuals themselves).$^{76}$

If additional health insurance really is so important that restrictive regulation is needed, would it not be better to integrate additional health insurance within the social security system? The poor, the sick and the old who cannot afford voluntary additional health insurance are not protected by government designed consumer protection rules regarding the additional health insurance market. As a consequence, regulation of additional health insurance protects

www.euro.who.int/en/about-us/partners/observatory/publications/studies/voluntaryhealth-insurance-in-europe-role-and-regulation, accessed 26 January 2017.

72 M. Whitehead, 'The concepts and principles of equity and health', International Journal of Health Services 22(3) (1992) 429-445.

73 World Health Organisation, Basic Documents, Forty-fifth edition, Supplement, October 2006, online at http://www.who.int/about/mission/en/, accessed 26 January 2017.

74 N. Söderlund, 'Possible objectives and resulting entitlements of essential health care packages', Health Policy 45(3) (1998) 195-208.

75 W.P.M.M. van de Ven, 'Choices in health care: a contribution from The Netherlands', British Medical Bulletin 51(4) (1995) 781-790.

76 L.M. Sabik and R.K. Lie, 'Priority setting in health care: lessons from the experience of eight countries', International Journal for Equity in Health 7(4) (2008) 1-13. 
only the well-off (or better-off) customers who can afford to buy additional health insurance. When additional health insurance covers essential healthcare, a more equitable result might be reached by integrating that care into the social security system rather than by developing restrictive regulation protecting only the well-off part of the population who can afford additional health insurance.

In Slovenia, where additional health insurance primarily covers copayments, lower income groups might be better served by a decrease in co-payments or by direct subsidies rather than by introducing restrictive regulation for voluntary additional health insurance.

In Belgium, additional health insurance mainly covers hospital care. About half of the money reimbursed by additional health insurance relates to the price of a stay in a private hospital room. Since quality of care in a private room is no better than in a double or common room, it might be difficult to uphold the view that special protection from government is needed to secure access to private hospital rooms.

New health technology is often reimbursed by additional health insurance. From an equity point of view - if essential healthcare services are concerned - new health technology should be integrated in basic health insurance rather than protecting only those customers who can afford additional cover.

Additional health insurance also provides financial protection from copayments. Traditionally, co-payments were introduced to reduce moral hazard..$^{77} \mathrm{Co}$-payments are meant to prevent people from seeking medical care that may not be necessary. Apart from their traditional role, co-payments also allow the public sector to shift costs on to households. ${ }^{78}$ In countries where private additional health insurance covers co-payments, the scope of statutory coverage might erode over time and there are concerns about the fact that those who do not have additional health insurance may face financial and other barriers to accessing healthcare. ${ }^{79}$

77 M. Chalkley and R. Robinson, Theory and Evidence on Cost Sharing in Health Care: An Economic Perspective (London: Office of Health Economics, 1997), online at https://www .ohe.org/publications/theory-and-evidence-cost-sharing-health-care-economicperspective, accessed 26 January 2017 .

78 S. Thomas, S. Thomson and T. Evetovits, 'Making sense of complementary health insurance', final report, Slovenian Ministry of Public Health, 2015, online at http://www.mz.gov .si/fileadmin/mz.gov.si/pageuploads/Analiza/21012016/21012016Report_Making_sense_ of_CHI_-_Slovenia.pdf, accessed 26 January 2017.

79 S. Thomson and E. Mossialos, 'Private health insurance in the European Union. Final report prepared for the European Commission, Directorate General for Employment, Social 
If there is insufficient public funding to reduce co-payments and to integrate (new) health technology within the mandatory basic health insurance system, basic health insurance could be extended with private funding. Low income groups, who cannot afford private funding, could be subsidised. The French government has chosen this option. In 2014, 7.4 per cent of those covered by additional health insurance benefited from a public programme providing free coverage to the poorest ('complementary universal health coverage', 'couverture maladie universelle complémentaire' (CMU-C)). ${ }^{80}$ Individuals with an income above the CMU-C ceiling can get a voucher to partially fund the premium for an additional health insurance contract ('aide complémentaire santé).

If all essential healthcare would be covered by an affordable basic health insurance scheme, there is no need to develop restrictive regulation for the voluntary additional health insurance market (covering non-essential healthcare) ${ }^{81}$ With all essential care being covered by the social security system, customers taking out voluntary health insurance would no more need special government protection than customers taking out home or car insurance.

In the Netherlands, the situation is clear-cut. According to the Dutch government, all essential healthcare is covered by mandatory basic health insurance. Voluntary additional health insurance, providing top-up cover for alternative medicine, dental care and physiotherapy, is not regulated by the government. ${ }^{82}$

However, as long as essential healthcare is not always reimbursed by mandatory basic health insurance and as long as statutory user charges (co-payments) remain quite substantial or fee supplements - extra billing - continue to exist, additional health insurance schemes may well be important for securing access to healthcare. In two Eu countries, France and Slovenia, private additional health insurance accounts for more than ten per cent of total health

Affairs and Equal Opportunities', London School of Economics, 24 June 2009, online at http://ec.europa.eu/social/BlobServlet?docId=4216\&langId=en accessed 26 January 2017.

80 C. Franc and A. Pierre, 'Compulsory private complementary health insurance offered by employers in France: implications and current debate', Health Policy 199(2) (2015) 111-116.

81 M.V. Pauly, 'A plan for a responsible national health insurance', Health Affairs 10(1) (1991) $5-25$.

82 See e.g., the letter of the Dutch government to the Parliament (Tweede Kamer) 'Beantwoording kamervragen over bericht dat vrouwen die zwanger zijn worden verwezen naar een andere zorgverzekeraar', 19 January 2016, online at https://www.rijksoverheid .nl/ministeries/ministerie-van-volksgezondheid-welzijn-en-sport/documenten/ kamerstukken/2016/01/19/beantwoording-kamervragen-over-bericht-dat-vrouwen-diezwanger-zijn-of-willen-worden-worden-verwezen-naar-een-andere-zorgverzekeraar, accessed 26 January 2017, 
expenditure. ${ }^{83}$ Markets with substantial statutory user charges have the highest levels of additional health insurance coverage. ${ }^{84}$ Over half of the Irish population is covered by additional health insurance which covers statutory user charges and reimbursement of treatment in private hospital beds. ${ }^{85}$ In countries where additional health insurance plays an important role, a regulatory framework has been developed to facilitate access and to protect consumers.

Free market and regulation need not be opposites. Competition does not exclude regulation. On the contrary, regulation can improve competition and help create a level playing field. Regulation can empower consumers, e.g., by creating more transparency (for instance, by obliging the use of standard clauses or even the use of standard contracts in additional health insurance). In the second half of the 1990s, the Office for Fair Trade (OFT), at the time the United Kingdom's regulatory agency for consumer protection, ${ }^{86}$ launched an investigation following concerns that customers lacked adequate information when buying private medical insurance. Regarding the ability of consumers to compare different products, the OFT reported: 'different plans are presented in different ways, and it is difficult — if not impossible for those outside the industry - to compare them in terms of value for money'. The ofT also found problematic 'the absence of information regarding past and likely future increases in the premium. ${ }^{87}$

A main obstacle for efficient and effective regulation is the information asymmetry between insurers and government. In Belgium, for instance, government regulation states that the medical index — used to adjust additional health insurance premiums to the evolution of healthcare costs - cannot be negative, even when cost evolution is negative. Such regulation may not be in the best interest of consumers. Another issue is that a medical index of this sort could act as a disincentive for insurance companies to reduce costs, because they know that in the end cost increases will be covered by the medical

83 France: 14.4 per cent (2014); Slovenia: 14.8 per cent (2015). Source: OECD Health Statistics 2016, see supra note 15 .

84 France: 95.5 per cent (2014); Slovenia: 72.8 per cent (2013). Source: OECD Health Statistics 2016, see supra note 15 .

85 D. McDaid, M. Wiley, A. Maresso and E. Mossialos, 'Ireland: Health system review', Health Systems in Transition 11(4) (2009) 1-268.

86 The ofT has since been replaced by the Competition and Markets Authority (смA).

87 T. Foubister, S. Thomson, E. Mossialos and A. McGuire, Private Medical Insurance in the United Kingdom (Brussels: European Observatory on Health Systems and Policies, 2006). 
index. In this way, the application of medical indices could even have an inflationary effect.

When all essential care is included in the social security system and barriers to care (e.g., high co-payments) have been removed, the market for voluntary additional health insurance could be opened to private - for profit or not for profit - companies with real competition actively being fostered. 
